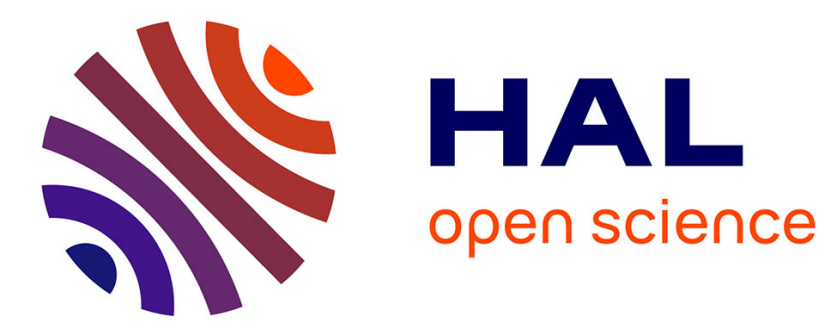

\title{
Production of Peroxy Radicals from the Photochemical Reaction of Fatty Acids at the Air-Water Interface
}

\author{
N. Hayeck, I. Mussa, S. Perrier, C. George
}

\section{To cite this version:}

N. Hayeck, I. Mussa, S. Perrier, C. George. Production of Peroxy Radicals from the Photochemical Reaction of Fatty Acids at the Air-Water Interface. ACS Earth and Space Chemistry, 2020, 4 (8), pp.1247-1253. 10.1021/acsearthspacechem.0c00048 . hal-02937469

\section{HAL Id: hal-02937469 \\ https://hal.science/hal-02937469}

Submitted on 18 Nov 2020

HAL is a multi-disciplinary open access archive for the deposit and dissemination of scientific research documents, whether they are published or not. The documents may come from teaching and research institutions in France or abroad, or from public or private research centers.
L'archive ouverte pluridisciplinaire HAL, est destinée au dépôt et à la diffusion de documents scientifiques de niveau recherche, publiés ou non, émanant des établissements d'enseignement et de recherche français ou étrangers, des laboratoires publics ou privés. 


\section{Production of peroxy radicals from the}

2 photochemical reaction of fatty acids at the air-water

3 interface

$4 \quad$ Nathalie Hayeck ${ }^{\ddagger}$, Ibrahim Mussa, Sébastien Perrier, and Christian George*

5 Univ Lyon, Université Claude Bernard Lyon 1, CNRS, IRCELYON, F-69626, Villeurbanne, 6 France.

8 ABSTRACT: Peroxy radicals are known for their role in tropospheric photochemistry as

9 intermediates in the oxidation of volatile organic compounds, leading to the formation of ozone

10 and organic nitrate compounds. Similarly, in the particle phase, peroxy radicals, considered a type

11 of reactive organic species (ROS), are also involved in many chemical transformations and

12 produce a consequential fraction of aerosols with an impact on health. Here, we show that peroxy

13 radicals are efficiently produced at the air/water interface upon irradiation of an organic film made

14 of a simple fatty acid (i.e., nonanoic acid). This source of peroxy radicals was quantified as 0.27

15 ppbv after interfacial titration of the peroxy radicals by nitric oxide in a photochemical flow

16 reactor. Using a combination of proton transfer reaction - time of flight - mass spectrometry (PTR-

17 ToF-MS) and ultrahigh performance liquid chromatography - heated electrospray ionization -

18 high resolution orbitrap - mass spectrometry (UHPLC-HESI-HR Orbitrap-MS), the products of 
19 this photochemistry were identified in the presence and absence of NO. The amount of peroxy

20 radicals produced by this photochemistry was comparable to those measured in surface water, or

21 the ROS bounded to ambient secondary organic aerosols. Accordingly, the photochemistry of

22 surfactant at the air/water interface might play a significant role in the health impact of organic

23 aerosols.

24 KEYWORDS Peroxy radicals, Reactive oxygen species, nonanoic acid, photochemistry, air-

25 water interface.

26

27 


\section{INTRODUCTION}

29 The oxidative capacity of the atmosphere is obviously gaining a lot of attention for its important

30 role in controlling air quality, but also through the production of ROS due to their effects on human

31 health ${ }^{1}$. The broadened definition of ROS includes oxygen-derived free radicals such as peroxy

32 radicals $\left(\mathrm{RO}_{2}{ }^{\circ}\right)^{1-4}$, which play a central role in the oxidation of volatile organic compounds

33 (VOCs). They can react with other radicals present in the atmosphere such as $\mathrm{NO}, \mathrm{NO}_{2}, \mathrm{HO}_{2}$ or

34 other peroxy radicals ${ }^{5}$, and are therefore essential in the budget of tropospheric ozone via the

35 production of $\mathrm{NO}_{2}{ }^{6}$. Although this production has been known for decades, recent measurements

36 of $\mathrm{OH}$ and $\mathrm{HO}_{2}$ radicals have shown disagreements with modeled $\mathrm{O}_{3}$ concentrations ${ }^{7-9}$. These

37 findings, together with subsequent investigations, pointed toward unknown reactions involving or

38 producing peroxy radicals as the reason for the difference between observed and modeled $\mathrm{O}_{3}$ levels

$39{ }^{8-11}$. Recent theoretical and experimental studies have now shown that peroxy radicals also play an

40 important role in the initiation of new particle formation via the production of highly oxygenated

41 organic molecules (HOMs) ${ }^{12-14}$.

42 Surface active compounds (i.e., surfactants) are omnipresent at air/water interfaces. In the

43 atmosphere, those surfaces are found on aerosol particles, lakes and oceans, which cover more

44 than $70 \%$ of the Earth ${ }^{15}$. Very recently, it has been shown that the surface propensity of these

45 surfactants in the sea surface microlayer (SML), which corresponds to the uppermost layer of

46 oceans, combined with the presence of photosensitizing compounds such as dissolved organic

47 matter, induce unique photochemical reactions with a significant effect on the climate. This impact

48 is materialized through their contribution to the formation of organic aerosols ${ }^{16-18}$, the abiotic

49 production of VOCs ${ }^{19-24}$ or by acting as sinks for atmospheric gases such as $\mathrm{O}_{3}$ and $\mathrm{NO}_{2}{ }^{25-28}$. It

50 was also shown that even a simple monolayer of fatty acid (namely, nonanoic acid) at the air/water 
51 interface can be photolyzed under actinic conditions, due to a slight red shift of its absorption

52 spectrum. Such an organic film, when exposed to light in the absence of any photosensitizer, 53 produces unsaturated and functionalized VOCs ${ }^{23}$. The authors suggested that these VOCs arise

54 from complex chemistry involving the production of peroxy radicals at the air/water interface.

55 Here, we investigated this interfacial peroxy radical production by studying the chemistry of 56 nitric oxide, acting as a trap for radicals at the surface of the water. This chemistry is discussed in 57 association with the titration of $\mathrm{RO}_{2}{ }^{\circ}$ radicals produced by the photochemistry of nonanoic acid. 58 Moreover, the VOCs produced were identified using a proton transfer reaction time-of-flight mass 59 spectrometer (PTR-ToF-MS). At the same time, the liquid phase composition was monitored using 60 ultra-high performance liquid chromatography coupled to a high-resolution mass spectrometer 61 (UHPLC-HR Orbitrap-MS).

62

\section{EXPERIMENTAL SECTION}

65 The system used here is similar to the one deployed in our previous investigations ${ }^{20,23}$. In short, 66 a cylindrical quartz reactor with a path length of $7 \mathrm{~cm}$ and an internal diameter of $1.6 \mathrm{~cm}$ was used 67 as a photochemical reactor (internal volume $\sim 14 \mathrm{~mL}$ ). It was typically half filled with pure water 68 with a mono to multilayer coverage of nonanoic acid. This reactor was then irradiated with a xenon 69 arc lamp (150 W, LOT-Quantum Design, France) placed at a distance of $13 \mathrm{~cm}$ from the 70 photochemical reactor to mimic the solar irradiation at the Earth's surface. To avoid excessive

71 heating of the reactor, a quartz water filter was placed in front of the lamp to remove infrared

72 irradiation. An additional Pyrex filter was used to eliminate the light in the UV region i.e., 73 wavelengths lower than $290 \mathrm{~nm}$. A total flow of $300 \mathrm{ml} \cdot \mathrm{min}^{-1}$ of a mixture of air and NO was 
74 continuously flowing through the reactor and analyzed using a $\mathrm{NO}_{\mathrm{x}}$ analyzer. Identification of

75 VOCs emitted in the gas phase was performed using commercial PTR-ToF-MS. Condensed phase

76 products were analyzed by means of UHPLC ( \pm ) HESI-Orbitrap-MS (Figure S1).

$77 \quad$ 2.2.Gas-phase measurements

$78 \mathrm{NO}$ and $\mathrm{NO}_{2}$ concentrations were monitored simultaneously using a chemiluminescence NO

79 detector (CLD 88p, Eco Physics, Switzerland) coupled to a photolytic converter (PLC 860, Eco

80 Physics, Switzerland), equipped with a metal halide discharge lamp converting $\mathrm{NO}_{2}$ to $\mathrm{NO}$ prior

81 to the detection by the CLD. The $\mathrm{NO}_{2}$ mixing ratios were corrected by the conversion factor of the

82 photolytic converter. With this instrument, a detection limit of 0.25 ppbv was achieved.

83 The photochemically produced VOCs, in presence or absence of NO, were monitored using a

84 selected reagent ion-proton transfer reaction time of flight mass spectrometer (SRI-PTR-ToF-MS

85 8000, Ionicon Analytik GmbH, Innsbruck, Austria) in $\mathrm{H}_{3} \mathrm{O}^{+}$and $\mathrm{NO}^{+}$modes. Air was sampled at

86 a constant flow of $100 \mathrm{~mL} / \mathrm{min}$ at an inlet temperature of $60^{\circ} \mathrm{C}$ for both ionization modes. For the

$87 \mathrm{H}_{3} \mathrm{O}^{+}$mode, a drift voltage of $500 \mathrm{~V}$, a drift temperature of $60^{\circ} \mathrm{C}$ and a drift pressure of $2 \mathrm{mbar}$

88 were used, resulting in an $\mathrm{E} / \mathrm{N}$ of about $125 \mathrm{Td}$. When $\mathrm{NO}^{+}$mode was used, the settings led to a

89 low E/N of about $93 \mathrm{Td}$, which was suitable to detect nitrate organic compounds but not too low

90 to avoid water cluster formation ${ }^{29}$.

$91 \quad$ 2.3. Condensed-phase measurements

92 The organic composition of the liquid phase was analyzed by ultra-high-performance liquid

93 chromatography (Dionex 3000, Thermo Scientific, USA) coupled to a high resolution Orbitrap

94 mass spectrometer (QExactive, Thermo Scientific, Germany). Analytes were separated on a

95 Waters Acquity HSS T3 column $(1.8 \mu \mathrm{m}, 2.1 \times 100 \mathrm{~mm})$ using acidified water (eluent A: 0.1\%,

96 v/v, formic acid; Optima LC/MS, Fisher Scientific, USA) and acidified acetonitrile (eluent B: 
$970.1 \%, v / v$, formic acid; Optima LC/MS, Fisher Scientific, USA) as the mobile phase. The

98 QExactive was equipped with a heated electrospray ionization source (HESI) used to apply a

99 voltage of $-3.0 \mathrm{kV}$ in negative mode and $3.2 \mathrm{kV}$ in positive mode. The auxiliary gas flow rate was

100 set to 25 arbitrary units (a.u.) and the sheath gas flow rate to 42 a.u. A heater temperature of $250^{\circ} \mathrm{C}$

101 and a capillary temperature of $350^{\circ} \mathrm{C}$ were used. The highest mass resolution of $140000 \mathrm{at} \mathrm{m} / \mathrm{z}$

102200 was used. A daily mass calibration was performed for the mass range of $\mathrm{m} / \mathrm{z}$ 50-750 using a 2

103 mM of sodium acetate solution ${ }^{23}$.

104 Each sample was divided into two aliquots; the first one was analyzed directly after filtration.

105 The second one underwent a derivatization process using an excess of a PFBHA (o-(2, 3, 4, 5, 6-

106 pentafluorobenzyl) hydroxylamine hydrochloride, Sigma Aldrich, $\geq 99.0 \%$ ) in order to identify

107 the organic compounds containing carbonyl functional groups present in the sample ${ }^{30}$. For this, $108200 \mu \mathrm{L}$ of the sample was mixed with $800 \mu \mathrm{L}$ of the PFBHA solution $(1 \mathrm{mg} / \mathrm{mL})$. The mixture was

109 left in darkness at room temperature for $24 \mathrm{~h}$ before analysis. Three replicates of direct and 110 derivatized analyses were assessed for each sample. Data processing and evaluation were 111 performed using XCalibur 2.2 (Thermo, USA). Formula assignment of the identified compounds 112 were achieved using a mass tolerance of $2 \mathrm{ppm}$.

\section{RESULTS AND DISCUSSION}

115 The production of peroxy radicals, as intermediates in the photochemistry of nonanoic acid, was 116 assessed by the reactive uptake of nitric oxide. Effectively, when the organic fatty acid film was 117 exposed to $120 \mathrm{ppbv}$ of NO in pure air, a decrease in the level of $1.1 \mathrm{ppbv}$ NO was observed 118 solely when the system was irradiated (Figure 1). This decrease in the NO concentration is 119 understood as being induced by the conversion of NO by the peroxy radicals produced via the 
120 photochemical reaction of nonanoic acid, as described by Rossignol et al. ${ }^{23}$, with 1:1 121 stoichiometry. However, this $\mathrm{NO}$ conversion was accompanied by only a minimal increase in $\mathrm{NO}_{2}$, 122 mostly within the noise of our detector.

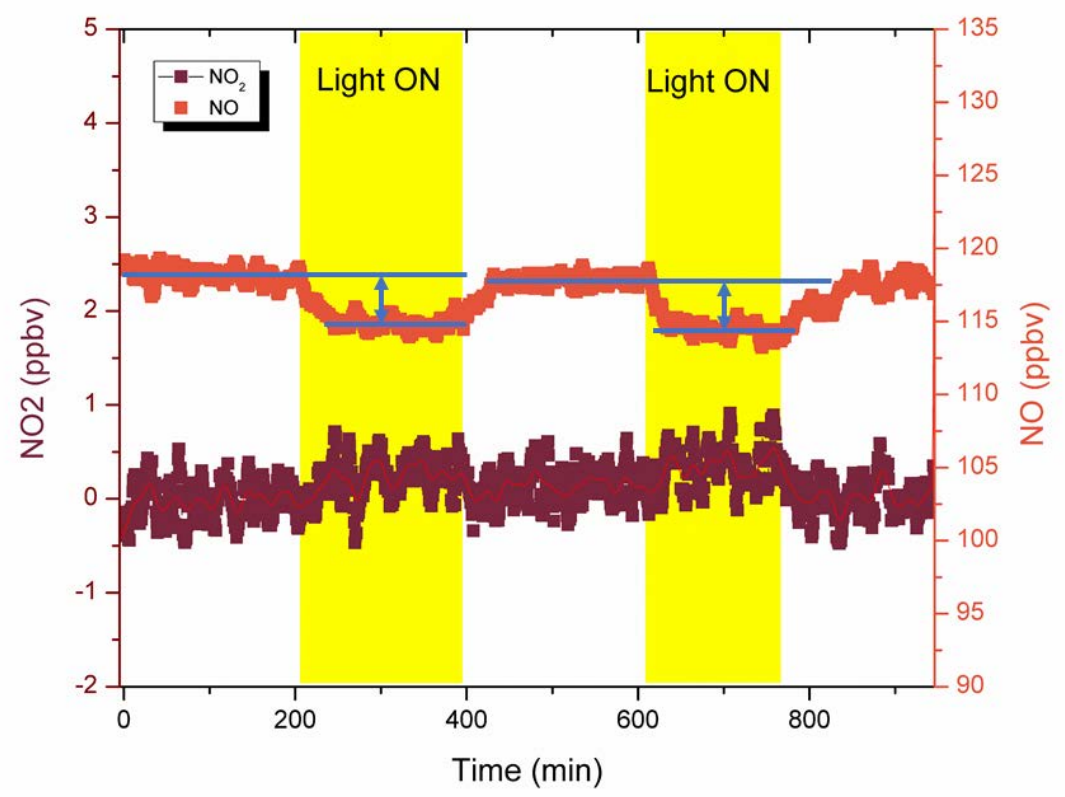

123

124 Figure 1. NO concentration measured in the photochemical reactor when the reactor was 125 irradiated and under dark conditions.

126 Our experimental approach did not allow us to resolve the uptake kinetics of NO, but allowed the 127 determination at steady-state (which was established very rapidly, as shown in Figure 1) of the 128 amount of NO lost at the air/water interface due to the photochemical production of peroxy 129 radicals. The amount of NO lost depends on the initial gaseous NO concentration, as shown in 130 Figure 2. Therefore, to use this information quantitatively, we performed some experiments at 131 higher concentrations, i.e. $120 \mathrm{ppbv} \mathrm{NO}$, where the reaction between $\mathrm{RO}_{2}$ radicals and NO 132 dominates over the self-reaction and cross-reaction of peroxy radicals, as shown by the plateau in 133 Figure 2 above $100 \mathrm{ppb}{ }^{31,32}$. At low NO mixing ratios. i.e. between 30 and 80 ppbv, the loss 134 increased (almost linearly) and levelled off at a NO mixing ratio greater than $100 \mathrm{ppbv}$. In other 
135 words, at concentrations lower than 100 ppbv, self- and cross-reactions of $\mathrm{RO}_{2}$ are possible, while

136 at higher values, the $\mathrm{NO}-\mathrm{RO}_{2}$ reaction dominates. Therefore, a mixing ratio of $120 \mathrm{ppbv}$ was

137 used in this study to quantitatively determine the amount of peroxy radicals produced by the

138 photochemistry of nonanoic acid.

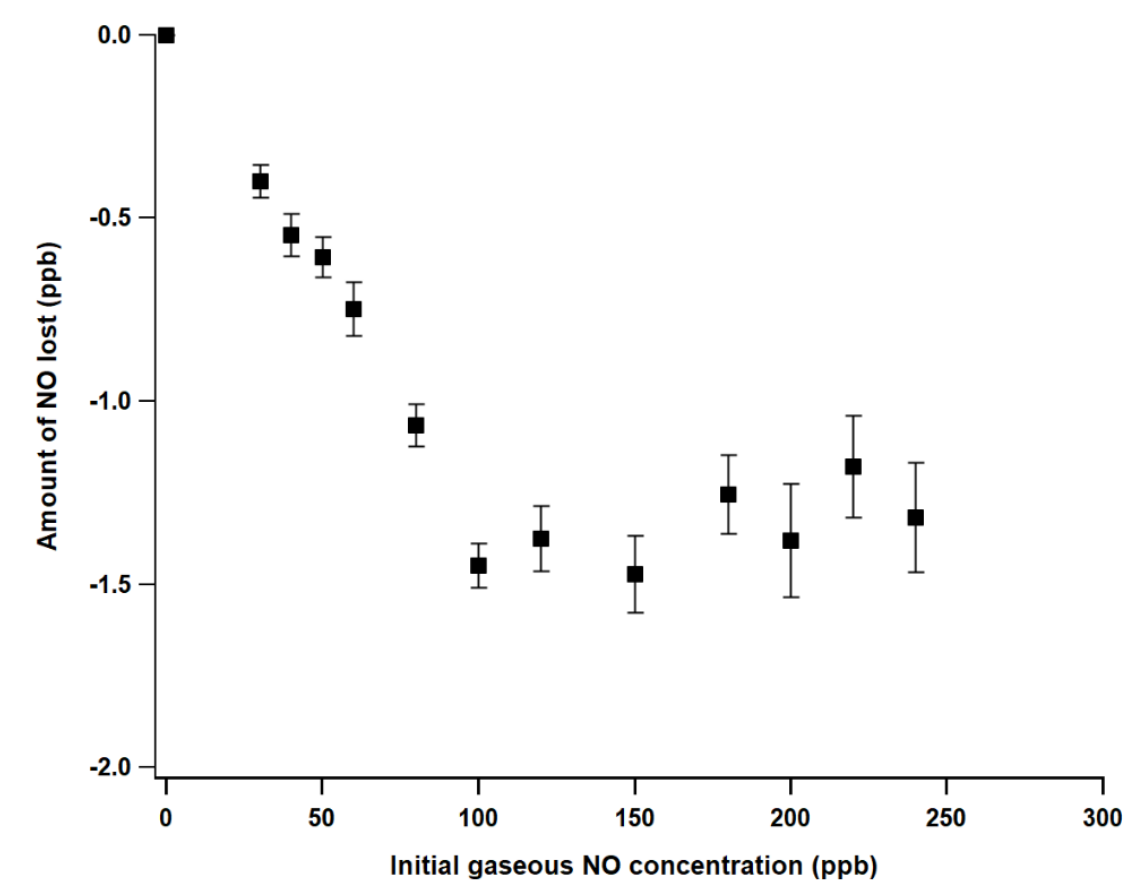

140 Figure 2. The amount of NO lost during the photochemical reaction as a function of the initial

141 gaseous concentration of NO in the gas phase of the reactor.

142 In Figure 3, only two pathways from the mechanism suggested by Rossignol et al. ${ }^{23}$ are 143 represented, due to their effect on peroxy radical formation and therefore on NO uptake on 144 irradiated nonanoic acid films. The first pathway produces a $\mathrm{C}_{9}$-aldehyde $\left(\mathrm{C}_{9} \mathrm{H}_{16} \mathrm{O}\right)$ and $\mathrm{OH}$ 145 radicals as intermediates. Since it is well-known that $\mathrm{NO}$ can react with $\mathrm{OH}^{\circ}$, any loss of NO due 146 to this reaction should be taken into account. We therefore studied the production of this $\mathrm{C}_{9}$ 147 aldehyde, which is initiated by either homolytic cleavage or an inter-molecular Norrish II reaction $148{ }^{23}$. Homolytic cleavage (reaction A) produces $\mathrm{OH}$ radicals, which could abstract an $\mathrm{H}$ atom from 
149 a saturated aldehyde $\left(\mathrm{C}_{9} \mathrm{H}_{18} \mathrm{O}\right)$ to produce an unsaturated aldehyde $\left(\mathrm{C}_{9} \mathrm{H}_{16} \mathrm{O}\right)$. In order to 150 investigate the possible reaction between $\mathrm{NO}$ and $\mathrm{OH}^{*}$, the products of the reaction involving $\mathrm{OH}^{*}$ 151 radicals as a reagent were compared in the presence and absence of NO. An unsaturated $\mathrm{C}_{9}$ 152 aldehyde $\left(\mathrm{C}_{9} \mathrm{H}_{16} \mathrm{O}\right)$ was found to be present at similar amounts in both cases, as shown in Figure

153 4. As shown by reaction $\mathrm{A}$ in Figure 3, $\mathrm{H}$ abstraction from the saturated aldehyde can be done by 154 an excited nonanoic acid molecule [NA]* as well. [NA]* does not compete with OH radicals since, 155 according to a quantum chemical investigation into the photochemical reaction of nonanoic acid 156 at an air-water interface, dehydrogenation of the saturated aldehyde by an $\mathrm{OH}$ radical is easier than 157 that by an excited nonanoic acid molecule [NA ${ }^{*}{ }^{33}$. Therefore, the formation of the unsaturated 158 aldehyde $\left(\mathrm{C}_{9} \mathrm{H}_{16} \mathrm{O}\right)$ is due to the reaction of $\mathrm{OH}$ radicals with the saturated aldehyde $\left(\mathrm{C}_{9} \mathrm{H}_{18} \mathrm{O}\right)$. As 159 shown in Figure 4, an unsaturated aldehyde is formed in the presence and absence of NO, which 160 means that, when NO is present, $\mathrm{OH}$ radicals do not react with $\mathrm{NO}$ but rather with the saturated 161 aldehyde $\left(\mathrm{C}_{9} \mathrm{H}_{18} \mathrm{O}\right)$ to produce the unsaturated aldehyde $\left(\mathrm{C}_{9} \mathrm{H}_{16} \mathrm{O}\right)$. Thus, the reaction between NO 162 and $\mathrm{OH}$ radicals does not compete with the one between $\mathrm{NO}$ and carboxyperoxy radicals $163\left(\mathrm{C}_{9} \mathrm{H}_{17} \mathrm{O}_{4}{ }^{*}\right)$. 


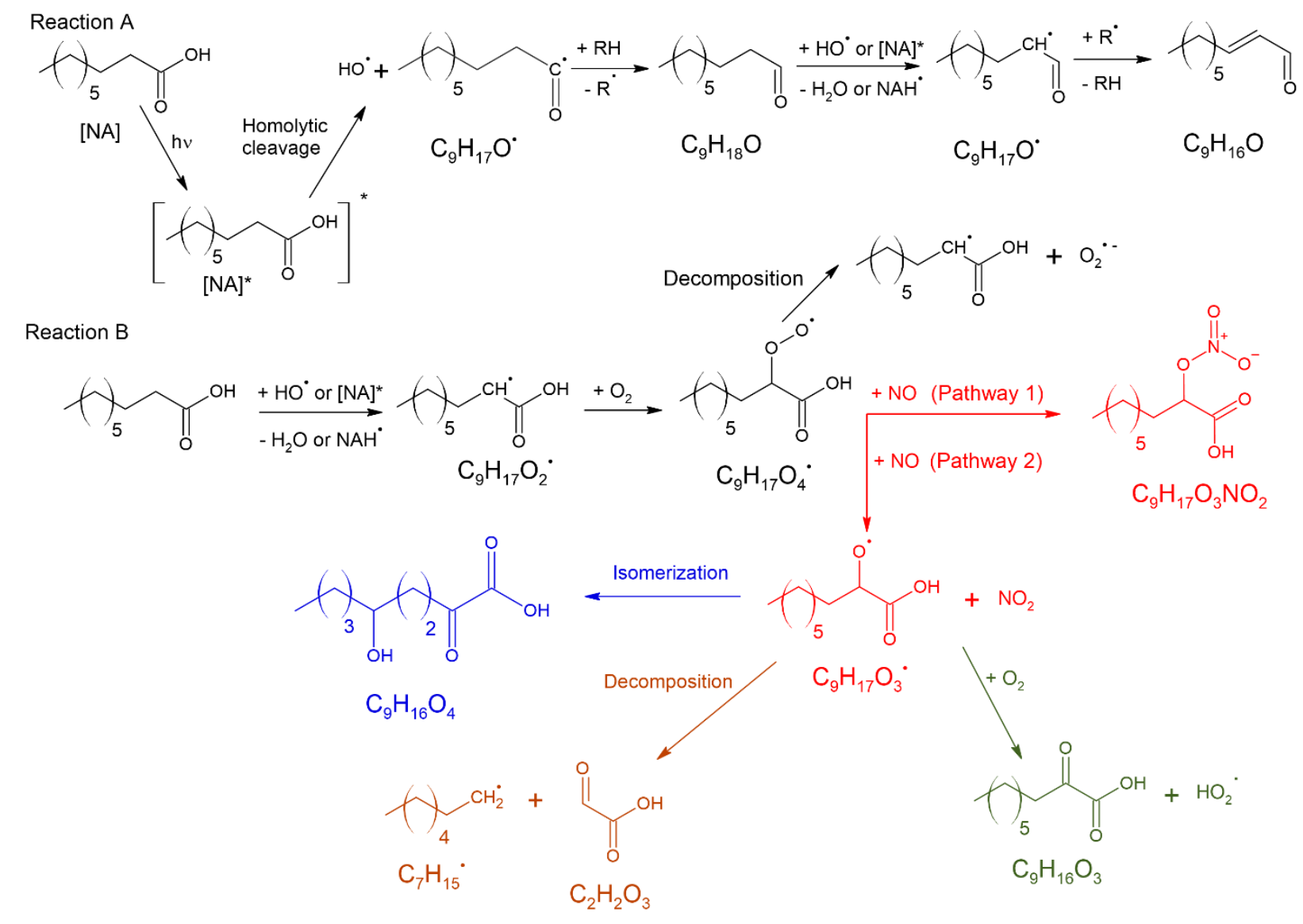

165 Figure 3. Photochemical mechanism of nonanoic acid (modified from ${ }^{23}$ ) with the possible

166 reactions of the peroxy radical with NO. [NA] represents a nonanoic acid molecule, while [NA]*

167 stands for a nonanoic acid molecule in the excited state. $\mathrm{NAH}^{\bullet}$ is a nonanoic acid molecule after

168 the abstraction of one hydrogen atom from another molecule.

169 As shown by reaction $\mathrm{B}$ in Figure 3, the radical $\mathrm{C}_{9} \mathrm{H}_{17} \mathrm{O}_{2}{ }^{\cdot}$ reacts with oxygen to produce the 170 carboxy peroxy radical $\left(\mathrm{C}_{9} \mathrm{H}_{17} \mathrm{O}_{4}{ }^{\circ}\right)$. As previously explained, the carboxy peroxy radical reacts 171 with NO via two pathways, which leads to the decrease in the NO concentration. In the absence of 172 oxygen, no peroxy radicals can be produced and the concentration of NO remains constant during 173 the photochemical reaction. In order to validate the presence of peroxy radicals in this 174 photochemical reaction, the same photochemical experiment was conducted in the absence of 
175 oxygen, i.e., under pure nitrogen. The water was bubbled with a gentle nitrogen stream to remove 176 any dissolved oxygen, and therefore prevent the formation of peroxy radicals. Figure 5 shows the 177 changes in the amount of NO taken up when the reactor was irradiated (yellow highlight) under 178 nitrogen or air as the dilution gas. As highlighted by the smoothed red line, a very small decrease 179 of NO was observed when the reactor was irradiated under nitrogen. However, when air was 180 present in the reactor, more notable uptake of NO was clearly observed. The latter confirms the 181 role of oxygen, and possibly the formation of peroxy radicals, in NO uptake. The slight decrease 182 in the NO mixing ratio under nitrogen could be due to the presence of a small amount of oxygen 183 in the reactor or to the reaction of $\mathrm{NO}$ with $\mathrm{OH}^{*}$ produced by the first reaction with nonanoic acid.

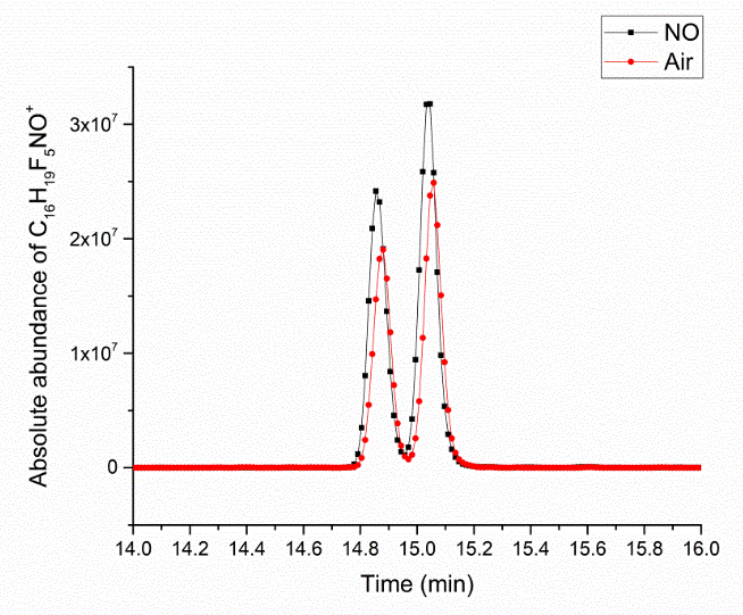

184

185 Figure 4. Chromatographic peaks corresponding to the derivatized ion of the aldehyde $\mathrm{C}_{9} \mathrm{H}_{16} \mathrm{O}$

186 According to reaction B of the mechanism shown in Figure 3, the carboxy peroxy radical $187\left(\mathrm{C}_{9} \mathrm{H}_{17} \mathrm{O}_{4}{ }^{*}\right)$ may react with NO via two pathways, or decompose ${ }^{34}$. The first one (pathway 1 ) 188 produces complex organic nitrate compounds $\left(\mathrm{C}_{9} \mathrm{H}_{17} \mathrm{O}_{3} \mathrm{NO}_{2}\right)$, while the second one leads to an 189 alkoxy radical $\left(\mathrm{C}_{9} \mathrm{H}_{17} \mathrm{O}_{3}{ }^{\circ}\right)$ and $\mathrm{NO}_{2}$, which did not increase significantly here (Figure 1). 


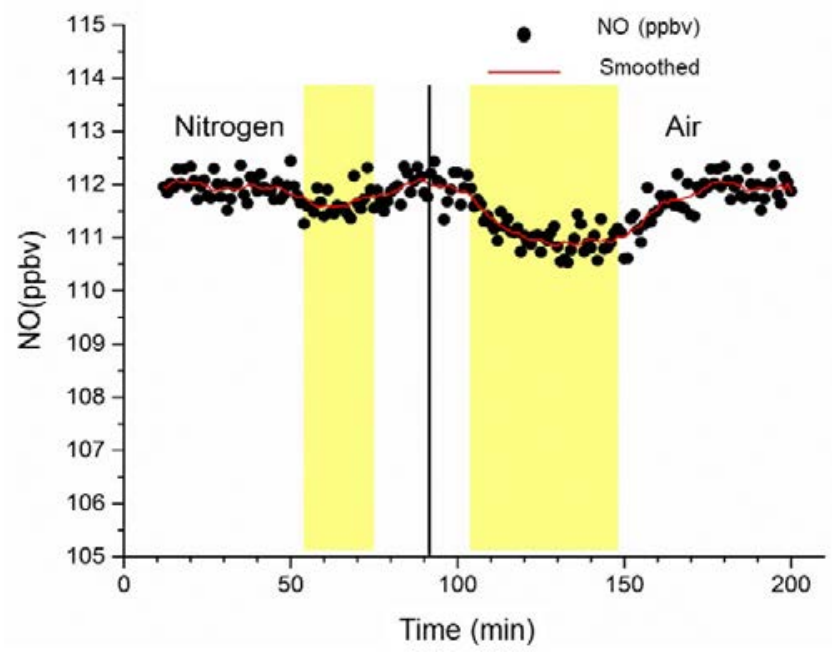

191 Figure 5. NO uptake under nitrogen flow on the left and air flow on the right.

192 However, we did not detect any organic nitrate compounds in the gas or in the liquid phases.

193 Previous studies on gaseous alkyl nitrate formation from the reactions of $\mathrm{C}_{8}-\mathrm{C}_{14} \mathrm{n}$-alkanes with

194 OH radicals in the presence of NO showed that the branching ratios for the formation of secondary

195 alkyl nitrates are similar for all isomers of a particular carbon number; average values of alkyl

196 nitrate yields were 0.219 and 0.254 for reactions of n-octane and n-dodecane, respectively. The

197 alkyl nitrate yields increased to a plateau of 0.3 for alkyls of $\mathrm{C}_{13}$ and $\mathrm{C}_{14}{ }^{35}$. Even though no studies

198 have been conducted to determine the direct effect of the presence of a carboxylic group adjacent

199 to a peroxy group, the absence of alkyl nitrate compounds in our experiments could be explained

200 by the presence of the carboxylic group, which has a double role in reducing the alkyl nitrate yield.

201 First, the presence of the carboxylic group may induce a net decrease in the yield of organic nitrate

202 by a factor of $3^{36}$. In addition, the presence of a hydroxyl group on an adjacent carbon ( $\beta$ -

203 hydroxyperoxy) reduces the branching ratio by 46\% compared to the branching ratio of an alkyl

204 peroxy radical. These authors related this to hydrogen bonding between the hydroxy and the

205 peroxy radical ${ }^{37}$. Based on these two conclusions, organonitrate production from the carboxy 206 peroxy radical $\left(\mathrm{C}_{9} \mathrm{H}_{17} \mathrm{O}_{4}{ }^{\circ}\right)$ could be inhibited or at least reduced to very low concentrations. Since 
207 the photochemical process studied in this work takes place at an air-water interface, the products

208 of this reaction are expected to be divided between the gas phase and the aqueous phase. Therefore,

209 the amounts of organonitrate present in the gas phase and the liquid phase were probably lower

210 than the limits of detection of the PTR-ToF-MS and the HESI-Orbitrap MS, which explains the

211 absence of any organonitrate compounds produced from the reaction of the carboxyperoxy radical

212 and NO.

213 The second pathway (pathway 2 in Figure 3) in the reaction of NO with the carboxyperoxy

214 radical was observed to be the major one, since the isomerization product $\left(\mathrm{C}_{9} \mathrm{H}_{16} \mathrm{O}_{4}\right)$ and the

215 oxidation product $\left(\mathrm{C}_{9} \mathrm{H}_{16} \mathrm{O}_{3}\right)$ of the alkoxy radical $\left(\mathrm{C}_{9} \mathrm{H}_{17} \mathrm{O}_{3}{ }^{\circ}\right)$ were formed exclusively under $\mathrm{NO}$

216 (Figure S3 and Figure S4). These isomerization and oxidation reactions are well-documented for

217 alkoxy radicals derived from linear and cyclic alkanes ${ }^{38}$. To the best of our knowledge, no studies

218 have been conducted on carboxyalkoxy radicals. Nevertheless, our study showed the presence of

219 the isomerization product $\mathrm{C}_{9} \mathrm{H}_{16} \mathrm{O}_{4}$ having, in addition to the carboxylic function, the same

220 functions as hydroxycarbonyls formed from the alkoxy radical isomerization reactions. This

221 compound is produced due to the formation of a six-membered ring (cf. SI) ${ }^{31,39}$. The

222 decomposition product $\mathrm{C}_{2} \mathrm{H}_{2} \mathrm{O}_{3}$ was not detected in the samples as a product of the reaction in the 223 presence of NO.

224 The detection of these products also demonstrates that the decomposition of peroxy radicals, 225 which produces $\mathrm{O}_{2}{ }^{-34}$, proceeds on time scales longer that the $\mathrm{RO}_{2}+\mathrm{NO}$ reaction. In fact, such 226 unimolecular decomposition is enabled only for alcohols. In the case of carboxylic acids, the 227 peroxyl group is only next to a $\mathrm{CO}_{2} \mathrm{H}$ group and it appears that the peroxyradical is the more 228 electronegative substituent, leading to quite slow unimolecular decomposition.

$229 \quad$ 3.1. Environmental implications 
230 In order to compare our results with field results, it is important to correct the observed loss of

231 NO by the ratio between the real solar irradiation and the xenon lamp output in the range between

232280 and $330 \mathrm{~nm}$, where nonanoic acid absorbs light and reacts photochemically. Scaling down to

233 real actinic conditions (cf. SI), and using the actual flow conditions in our reactor, and finally

234 assuming that one NO titrates one peroxy radical, the aqueous steady-state formation rate $\mathrm{R}_{\mathrm{f}}$ of

$235 \mathrm{RO}_{2}$ can be approximated by the following equation:

236

$$
R_{f} \approx \frac{\Delta N O \times F_{g}}{V_{a q}}
$$

Eq. 1

237 Where, $\Delta \mathrm{NO}$ is the amount of NO lost $(0.27 \mathrm{ppb})$, Fg the gas flow rate $\left(300 \mathrm{~mL} \mathrm{~min}^{-1}\right)$ and finally

$238 \mathrm{~V}_{\mathrm{aq}}$ the liquid volume in which the reaction takes place. This volume can be defined by two limiting

239 cases, either the reaction takes place homogeneously in the aqueous volume of the reactor $(7 \mathrm{~mL})$

240 or in an outer shell defined by the local surface enrichment and diffusion limitations which

241 thickness can estimate to be $100 \mu \mathrm{m}$ similarly to the oceanic SML. Applying this equation to our

242 conditions leads to peroxy formation rates in the range from $8 \times 10^{-12}$ to $5 \times 10^{-10} \mathrm{M} \mathrm{s}^{-1}$. Interestingly,

243 those data compare favorably by those reported by Faust and Hoigné ${ }^{40,41}$ who reported midday

244 peroxy radical formation rates in the rate from $10^{-11}$ to $10^{-10} \mathrm{M} \mathrm{s}^{-1}$.

245 To derive the steady-state concentration of these peroxy radicals, one can estimate that in the

246 environment their main loss corresponds to their second-order self-recombination reaction, which

247 proceeds with a rate constant of ca. $2 \times 10^{7} \mathrm{M}^{-1} \mathrm{~s}^{-1}{ }^{42}$. In this case, the steady-state concentration can

248 be calculated from:

$$
[R O O]_{S S}=\sqrt{\frac{R_{f}}{2 \times 10^{7}}}
$$

250 leading to concentrations in the range $6 \times 10^{-10}-6 \times 10^{-9} \mathrm{M}$. One could then speculate that if those 251 are in Henry's law equilibrium, then the concentration of peroxy radicals in the air aloft would be 
252 in the range $0.006-0.06 \mathrm{ppb}$ (assuming arbitrarily Henry's law constant of $100 \mathrm{M} \mathrm{atm}^{-1}$,

253 corresponding to the upper limit of reported values ${ }^{43}$ ). Several studies have been conducted to

254 measure $\mathrm{RO}_{2}{ }^{\bullet}$ radicals in the marine boundary layer ${ }^{10,44-47}$. In these studies, $\mathrm{RO}_{2}{ }^{*}$ radicals ranged

255 between 0.01 and $0.05 \mathrm{ppbv}$, depending on the season, the measurement location and the air

256 masses. Even though the values of this study are higher than those of previous work, the

257 photochemistry of surfactants could be an important source of peroxy radicals, which may

258 influence atmospheric chemistry models. As an example, Burkert et al. found that the atmospheric

259 model used to simulate the total amount of $\mathrm{RO}_{2}{ }^{\bullet}$ shows a discrepancy with actual measurements.

260 Therefore, they suggested that the presence of reactive non-methane hydrocarbons, which are not

261 measured and included in the model, are responsible for this disagreement ${ }^{24}$.

262 The experiments described above were performed on bulk solutions, and cannot therefore be 263 applied to aerosols. Nevertheless, in an attempt to scale up the bulk concentrations given above

264 for peroxy radicals to dispersed ultrafine particles, by normalizing the surface-to-volume ratio of 265 our reactor to those of $200 \mathrm{~nm}$ diameter sized particle with an average loading of $15 \mu \mathrm{g} \mathrm{m}^{-3},{ }^{48}$ we

266 obtain a ROS loading in the range of 0.14-1.4 ppb (hereby assuming that all peroxy radicals are 267 ROS in the condensed phase). This rough estimate is comparable to ambient particle-bound ROS 268 (PB-ROS) measured in different cities. The ambient ROS levels measured at a polluted urban site 269 in the UK varied between 0.098 and $0.59 \mathrm{ppbv}$ of equivalent $\left[\mathrm{H}_{2} \mathrm{O}_{2}\right]{ }^{48}$. An average ROS 270 concentration of $0.2 \mathrm{ppbv}$ of equivalent $\left[\mathrm{H}_{2} \mathrm{O}_{2}\right]$ was found during a study in Rochester, New York, 271 USA in $2011^{49}$, which is comparable in magnitude to the concentration of ROS found in our study. 272 Online measurements of PB-ROS in Beijing and Bern showed concentrations between 0.25 to 0.74 273 ppbv, and between 0.025 and 0.049 ppbv, respectively ${ }^{50}$. In addition, the authors found that PB274 ROS are correlated with the oxygenated organic fraction. They showed that this organic aerosol 
275 fraction contributed to more than $60 \%$ of the total PB-ROS. Considering the fact that surfactants

276 are concentrated in the organic matrix of aerosol particles ${ }^{15}$, this accordance in the results shows

277 the importance of the photochemistry of fatty acids studied here in terms of ROS production and

278 its effects on the atmosphere and human health.

279

4. CONCLUSION

281 In this work, the formation of peroxy radicals from the photochemistry of a nonanoic acid film

282 at an air/water interface was indirectly demonstrated. The study of the gas phase and liquid phase

283 products showed the absence of organic nitrate compounds because of the presence of the carboxyl

284 function in the nonanoic acid. On another hand, the reaction of peroxy radicals with NO led to the

285 formation of alkoxy radicals and subsequently new functionalized compounds formed by the 286 oxidation and isomerization of the alkoxy radical.

287 The total amount of peroxy radicals produced was assessed through a titration with nitric oxide 288 (NO). It was shown that the amount of peroxy radicals produced at the air/water interface coated 289 with a film of nonanoic acid is comparable to the concentration of peroxy radicals found in surface 290 water and is consistent with the fact that the SML is concentrated with organic compounds, i.e. 291 surfactants.

292 This study shows the importance of surfactant photochemistry in the oxidative capacity of the 293 atmosphere. Including the production of peroxy radicals from this photochemistry in atmospheric 294 models might explain the difference between the modeled and measured peroxy radicals in the 295 marine boundary layer. 
299 Supporting Information. Determination of the peroxy radicals produced by the photochemical 300 reaction of the nonanoic acid monolayer, Figure S1-S4 and Scheme S1. This material is available 301 free of charge via the Internet at http://pubs.acs.org.

\section{AUTHOR INFORMATION}

\section{Corresponding Author}

$305 *$ Dr. Christian George, CNRS-IRCELYON, 2 avenue Albert Einstein, 69626 Villeurbanne Cedex, 306 France. Email: Christian.george@ircelyon.univ-lyon1.fr; Phone: +33 (0) 472448190.

\section{Present Address}

$308{ }^{\ddagger}$ Now at the Chemistry Department, Faculty of Arts and Sciences, American University of Beirut, 309 Beirut, Lebanon.

\section{Author Contributions}

312 The manuscript was written with contributions from all authors. All authors have given approval 313 to the final version of the manuscript.

\section{Funding Sources}

315 This study was supported by the European Research Council under the European Union's 316 Framework Program (FP/2007-2013)/ERC Grant Agreement 290852 - AIRSEA. This project also 317 received funding from the European Union's Horizon 2020 research and innovation program under 318 grant agreement No. 690958 (MARSU). 


\section{Notes}

320 The authors declare no competing financial interests.

\section{Acknowledgments}

322 The authors are thankful to Nicolas Charbonnel for the technical support provided.

\section{Abbreviations}

324 ROS, Reactive Oxygen Species; VOCs, Volatile Organic Compounds; HOM, Highly Oxygenated 325 Organic Molecules; SML, Sea Surface Microlayer; PTR-ToF-MS, Proton Transfer Reaction Time326 of-Flight Mass Spectrometry; UHPLC-HR Orbitrap-MS, Ultra-high Performance Liquid 327 Chromatography High Resolution Mass Spectrometry; HESI, Heated Electrospray Ionization 328 Source; PFBHA, o-(2, 3, 4, 5, 6-pentafluorobenzyl) hydroxylamine; PB-ROS, Particle Bound 329 Reactive Oxygen Species 
333 1, Pöschl, U.; Shiraiwa, M. Multiphase Chemistry at the Atmosphere-Biosphere Interface Influencing Climate and Public Health in the Anthropocene. Chem. Rev. 2015, 115 (10), 44404475. https://doi.org/10.1021/cr500487s.

2. Anglada, J. M.; Martins-Costa, M.; Francisco, J. S.; Ruiz-López, M. F. Interconnection of Reactive Oxygen Species Chemistry across the Interfaces of Atmospheric, Environmental, and Biological Processes. Acc. Chem. Res. 2015, 48 (3), 575-583. https://doi.org/10.1021/ar500412p.

3. Birben, E.; Sahiner, U. M.; Sackesen, C.; Erzurum, S.; Kalayci, O. Oxidative Stress and

Antioxidant Defense: World Allergy Organ. J. 2012, 5 (1), 9-19. https://doi.org/10.1097/WOX.0b013e3182439613.

342 4. Winterbourn, C. C. Reconciling the Chemistry and Biology of Reactive Oxygen Species. Nat. Chem. Biol. 2008, 4 (5), 278-286. https://doi.org/10.1038/nchembio.85. Organic Compounds: Impacts on Air Quality and Climate. Chem. Rev. 2015, 115 (10), 39844014. https://doi.org/10.1021/cr500549n.

6. Pusede, S. E.; Steiner, A. L.; Cohen, R. C. Temperature and Recent Trends in the Chemistry of Continental Surface Ozone. Chem. Rev. 2015, 115 (10), 3898-3918. https://doi.org/10.1021/cr5006815.

$350 \quad$ 7. Martinez, M.; Harder, H.; Kubistin, D.; Rudolf, M.; Bozem, H.; Eerdekens, G.; Fischer,

H.; Konigstedt, R.; Parchatka, U.; Schiller, C. L.; Stickler, A.; Williams, J.; Lelieveld, J. Hydroxyl

352 Radicals in the Tropical Troposphere over the Suriname Rainforest: Airborne Measurements. Atmos Chem Phys 2010, 15, 3759-3773.

8. Hofzumahaus, A.; Rohrer, F.; Lu, K.; Bohn, B.; Brauers, T.; Chang, C.-C.; Fuchs, H.; Holland, F.; Kita, K.; Kondo, Y.; Li, X.; Lou, S.; Shao, M.; Zeng, L.; Wahner, A.; Zhang, Y. Amplified Trace Gas Removal in the Troposphere. Science 2009, 324 (5935), 1702-1704. 357 https://doi.org/10.1126/science.1164566.

358 9. Lelieveld, J.; Butler, T. M.; Crowley, J. N.; Dillon, T. J.; Fischer, H.; Ganzeveld, L.; 359 Harder, H.; Lawrence, M. G.; Martinez, M.; Taraborrelli, D.; Williams, J. Atmospheric Oxidation 360 Capacity Sustained by a Tropical Forest. Nature 2008, 452 (7188), 737-740. 361 https://doi.org/10.1038/nature06870. 
10. Burkert, J.; Andrés-Hernández, M. D.; Reichert, L.; Meyer-Arnek, J.; Doddridge, B.; 363 Dickerson, R. R.; Mühle, J.; Zahn, A.; Carsey, T.; Burrows, J. P. Trace Gas and Radical Diurnal 364 Behavior in the Marine Boundary Layer during INDOEX 1999. J. Geophys. Res. Atmospheres 365 2003, 108 (D8). https://doi.org/10.1029/2002JD002790.

366 11. Nozière, B.; Kalberer, M.; Claeys, M.; Allan, J.; D’Anna, B.; Decesari, S.; Finessi, E.; 367 Glasius, M.; Grgić, I.; Hamilton, J. F.; Hoffmann, T.; Iinuma, Y.; Jaoui, M.; Kahnt, A.; Kampf, C. 368 J.; Kourtchev, I.; Maenhaut, W.; Marsden, N.; Saarikoski, S.; Schnelle-Kreis, J.; Surratt, J. D.; 369 Szidat, S.; Szmigielski, R.; Wisthaler, A. The Molecular Identification of Organic Compounds in 370 the Atmosphere: State of the Art and Challenges. Chem. Rev. 2015, 115 (10), 3919-3983. 371 https://doi.org/10.1021/cr5003485.

372 12. Roldin, P.; Ehn, M.; Kurtén, T.; Olenius, T.; Rissanen, M. P.; Sarnela, N.; Elm, J.; Rantala, 373 P.; Hao, L.; Hyttinen, N.; Heikkinen, L.; Worsnop, D. R.; Pichelstorfer, L.; Xavier, C.; Clusius, 374 P.; Öström, E.; Petäjä, T.; Kulmala, M.; Vehkamäki, H.; Virtanen, A.; Riipinen, I.; Boy, M. The 375 Role of Highly Oxygenated Organic Molecules in the Boreal Aerosol-Cloud-Climate System. Nat. 376 Commun. 2019, 10 (1), 4370. https://doi.org/10.1038/s41467-019-12338-8.

377 13. Schervish, M.; Donahue, N. M. Peroxy Radical Chemistry and the Volatility Basis Set; 378 preprint; Gases/Atmospheric Modelling/Troposphere/Chemistry (chemical composition and reactions), 2019. https://doi.org/10.5194/acp-2019-509.

380 14. Zhao, Y.; Thornton, J. A.; Pye, H. O. T. Quantitative Constraints on Autoxidation and Dimer Formation from Direct Probing of Monoterpene-Derived Peroxy Radical Chemistry. Proc. Natl. Acad. Sci. 2018, 115 (48), 12142-12147. https://doi.org/10.1073/pnas.1812147115.

15. George, C.; Ammann, M.; D’ Anna, B.; Donaldson, D. J.; Nizkorodov, S. A. Heterogeneous Photochemistry in the Atmosphere. Chem. Rev. 2015, 115 (10), 4218-4258. https://doi.org/10.1021/cr500648z.

16. Alpert, P. A.; Ciuraru, R.; Rossignol, S.; Passananti, M.; Tinel, L.; Perrier, S.; Dupart, Y.; Steimer, S. S.; Ammann, M.; Donaldson, D. J.; George, C. Fatty Acid Surfactant Photochemistry Results in New Particle Formation. Sci. Rep. 2017, 7 (1). https://doi.org/10.1038/s41598-01712601-2.

390 17. Bernard, F.; Ciuraru, R.; Boréave, A.; George, C. Photosensitized Formation of Secondary 391 Organic Aerosols above the Air/Water Interface. Environ. Sci. Technol. 2016, 50 (16), 8678-8686. 392 https://doi.org/10.1021/acs.est.6b03520. 
18. Brüggemann, M.; Hayeck, N.; George, C. Interfacial Photochemistry at the Ocean Surface

394 Is a Global Source of Organic Vapors and Aerosols. Nat. Commun. 2018, 9 (1). 395 ,https://doi.org/10.1038/s41467-018-04528-7.

396 19. Brüggemann, M.; Hayeck, N.; Bonnineau, C.; Pesce, S.; Alpert, P. A.; Perrier, S.; Zuth, 397 C.; Hoffmann, T.; Chen, J.; George, C. Interfacial Photochemistry of Biogenic Surfactants: A 398 Major Source of Abiotic Volatile Organic Compounds. Faraday Discuss. 2017, 200, 59-74. 399 https://doi.org/10.1039/C7FD00022G.

400 20. Ciuraru, R.; Fine, L.; van Pinxteren, M.; D’Anna, B.; Herrmann, H.; George, C. 401 Photosensitized Production of Functionalized and Unsaturated Organic Compounds at the Air-Sea 402 Interface. Sci. Rep. 2015, 5 (1). https://doi.org/10.1038/srep12741.

403 21. Ciuraru, R.; Fine, L.; Pinxteren, M. van; D’Anna, B.; Herrmann, H.; George, C. 404 Unravelling New Processes at Interfaces: Photochemical Isoprene Production at the Sea Surface. 405 Environ. Sci. Technol. 2015, 49 (22), 13199-13205. https://doi.org/10.1021/acs.est.5b02388.

406 22. Fu, H.; Ciuraru, R.; Dupart, Y.; Passananti, M.; Tinel, L.; Rossignol, S.; Perrier, S.; 407 Donaldson, D. J.; Chen, J.; George, C. Photosensitized Production of Atmospherically Reactive 408 Organic Compounds at the Air/Aqueous Interface. J. Am. Chem. Soc. 2015, 137 (26), 8348-8351. 409 https://doi.org/10.1021/jacs.5b04051.

410 23. Rossignol, S.; Tinel, L.; Bianco, A.; Passananti, M.; Brigante, M.; Donaldson, D. J.; 411 George, C. Atmospheric Photochemistry at a Fatty Acid-Coated Air-Water Interface. Science 412 2016, 353 (6300), 699-702. https://doi.org/10.1126/science.aaf3617.

413 24. Tinel, L.; Rossignol, S.; Bianco, A.; Passananti, M.; Perrier, S.; Wang, X.; Brigante, M.; 414 Donaldson, D. J.; George, C. Mechanistic Insights on the Photosensitized Chemistry of a Fatty 415 Acid at the Air/Water Interface. Environ. Sci. Technol. 2016, 50 (20), 11041-11048. 416 https://doi.org/10.1021/acs.est.6b03165.

417 25. Carpenter, L. J.; Nightingale, P. D. Chemistry and Release of Gases from the Surface 418 Ocean. Chem. Rev. 2015, 115 (10), 4015-4034. https://doi.org/10.1021/cr5007123.

419 26. George, C.; Ammann, M.; D’ Anna, B.; Donaldson, D. J.; Nizkorodov, S. A. Heterogeneous 420 Photochemistry in the Atmosphere. Chem. Rev. 2015, 115 (10), 4218-4258. 421 https://doi.org/10.1021/cr500648z. 
27. Jammoul, A.; Dumas, S.; D’Anna, B.; George, C. Photoinduced Oxidation of Sea Salt 423 Halides by Aromatic Ketones: A Source of Halogenated Radicals. Atmos Chem Phys 2009, 9, $424 \quad 4229-4237$

425 28. Reeser, D. I.; Jammoul, A.; Clifford, D.; Brigante, M.; D’Anna, B.; George, C.; Donaldson, 426 D. J. Photoenhanced Reaction of Ozone with Chlorophyll at the Seawater Surface. J. Phys. Chem. 427 C 2009, 113 (6), 2071-2077. https://doi.org/10.1021/jp805167d.

428 29. Duncianu, M.; David, M.; Kartigueyane, S.; Cirtog, M.; Doussin, J.-F.; Picquet-Varrault, 429 B. Measurement of Alkyl and Multifunctional Organic Nitrates by Proton-Transfer-Reaction Mass 430 Spectrometry. Atmospheric Meas. Tech. 2017, 10 (4), 1445-1463. https://doi.org/10.5194/amt431 10-1445-2017.

432 30. Borrás, E.; Tortajada-Genaro, L. A. Determination of Oxygenated Compounds in 433 Secondary Organic Aerosol from Isoprene and Toluene Smog Chamber Experiments. Int. J. 434 Environ. Anal. Chem. 2012, 92 (1), 110-124. https://doi.org/10.1080/03067319.2011.572164.

435 31. Atkinson, R. Gas-Phase Tropospheric Chemistry of Volatile Organic Compounds: 1. 436 Alkanes and Alkenes. J. Phys. Chem. Ref. Data 1997, 26 (2), 215-290. 437 https://doi.org/10.1063/1.556012.

$438 \quad 32$ Z Ziemann, P. J.; Atkinson, R. Kinetics, Products, and Mechanisms of Secondary Organic 439 Aerosol Formation. Chem. Soc. Rev. 2012, 41 (19), 6582-6605. 440 https://doi.org/10.1039/C2CS35122F.

441 33. Xiao, P.; Wang, Q.; Fang, W.-H.; Cui, G. Quantum Chemical Investigation on 442 Photochemical Reactions of Nonanoic Acids at Air-Water Interface. J. Phys. Chem. A 2017, 121 443 (22), 4253-4262. https://doi.org/10.1021/acs.jpca.7b03123.

444 34. Sonntag, C. von; Schuchmann, H.-P. The Elucidation of Peroxyl Radical Reactions in 445 Aqueous Solution with the Help of Radiation-Chemical Methods. Angew. Chem. Int. Ed. Engl. 446 1991, 30 (10), 1229-1253. https://doi.org/10.1002/anie.199112291.

447 35. Yeh, G. K.; Ziemann, P. J. Alkyl Nitrate Formation from the Reactions of C8-C14 n448 Alkanes with $\mathrm{OH}$ Radicals in the Presence of $\mathrm{NO}(\mathrm{x})$ : Measured Yields with Essential Corrections 449 for Gas-Wall Partitioning. J. Phys. Chem. A 2014, 118 (37), 8147-8157. 450 https://doi.org/10.1021/jp500631v. 
36. Espada, C.; Grossenbacher, J.; Ford, K.; Couch, T.; Shepson, P. B. The Production of 452 Organic Nitrates from Various Anthropogenic Volatile Organic Compounds. Int. J. Chem. Kinet. 453 2005, 37 (11), 675-685. https://doi.org/10.1002/kin.20122.

454 37. Matsunaga, A.; Ziemann, P. J. Yields of $\beta$-Hydroxynitrates and Dihydroxynitrates in 455 Aerosol Formed from OH Radical-Initiated Reactions of Linear Alkenes in the Presence of NO x. J. Phys. Chem. A 2009, 113 (3), 599-606. https://doi.org/10.1021/jp807764d.

38. Kwok, E. S. C.; Arey, J.; Atkinson, R. Alkoxy Radical Isomerization in the OH RadicalInitiated Reactions of C4-C8 n-Alkanes. J. Phys. Chem. 1996, 100 (1), 214-219. https://doi.org/10.1021/jp952036x.

39. Atkinson, R.; Kwok, E. S. C.; Arey, J.; Aschmann, S. M. Reactions of Alkoxyl Radicals in the Atmosphere. Faraday Discuss. 1995, 100, 23. https://doi.org/10.1039/fd9950000023.

40. Faust, B. C.; Hoigne, J. Sensitized Photooxidation of Phenols by Fulvic Acid and in Natural Waters. Environ. Sci. Technol. 1987, 21 (10), 957-964.

41. Blough, N.V.; Zepp, R. G. Reactive Oxygen Species in Natural Waters. In Active Oxygen in Chemistry; Foote, C. S., Valentine, J. S., Greenberg, A., Liebman, J. F., Ed.; Structure energetics and reactivity in chemistry series; Blackie Academic \& Professional: London; New York, 1995.

42. Sonntag, C.V.; Schumann, H.P. The Elucidation of Peroxyl Radical Reactions in Aqueous Solution with the Help of Radiation-Chemical Methods. Angewandte Chemie Int. 1991, 30, 10. https://doi.org/10.1002/anie.199112291

43. Sander, R.; Compilation of Henry's law constants (version 4.0) for water as solvent. Atmos. Chem. Phys. 2015, 15, 4399-4981

44. Burkert, J.; Andrés-Hernández, M.-D.; Stöbener, D.; Burrows, J. P.; Weissenmayer, M.; Kraus, A. Peroxy Radical and Related Trace Gas Measurements in the Boundary Layer above the Atlantic Ocean. J. Geophys. Res. Atmospheres 2001, 106 (D6), 5457-5477. https://doi.org/10.1029/2000JD900613.

$480 \quad$ 46. Fleming, Z. L.; Monks, P. S.; Rickard, A. R.; Heard, D. E.; Bloss, W. J.; Seakins, P. W.; 481 Still, T. J.; Sommariva, R.; Pilling, M. J.; Morgan, R. Peroxy Radical Chemistry and the Control 
482 of Ozone Photochemistry at Mace Head, Ireland during the Summer of 2002. Atmospheric Chem. 483 Phys. 2006, 6 (8), 2193-2214.

484 47. Monks, P. Fundamental Ozone Photochemistry in the Remote Marine Boundary Layer the 485 Soapex Experiment, Measurement and Theory. Atmos. Environ. 1998, 32 (21), 3647-3664. 486 https://doi.org/10.1016/S1352-2310(98)00084-3.

487 48. Wragg, F. P. H.; Fuller, S. J.; Freshwater, R.; Green, D. C.; Kelly, F. J.; Kalberer, M. An 488 Automated Online Instrument to Quantify Aerosol-Bound Reactive Oxygen Species (ROS) for 489 Ambient Measurement and Health-Relevant Aerosol Studies. Atmospheric Meas. Tech. 2016, 9 490 (10), 4891-4900. https://doi.org/10.5194/amt-9-4891-2016.

491 49. Wang, Y.; Hopke, P. K.; Sun, L.; Chalupa, D. C.; Utell, M. J. Laboratory and Field Testing 492 of an Automated Atmospheric Particle-Bound Reactive Oxygen Species Sampling-Analysis 493 System. J. Toxicol. 2011, 2011, 1-9. https://doi.org/10.1155/2011/419476.

494 50. Zhou, J.; Elser, M.; Huang, R.-J.; Krapf, M.; Fröhlich, R.; Bhattu, D.; Stefenelli, G.; Zotter, 495 P.; Bruns, E. A.; Pieber, S. M.; Ni, H.; Wang, Q.; Wang, Y.; Zhou, Y.; Chen, C.; Xiao, M.; Slowik, 496 J. G.; Brown, S.; Cassagnes, L.-E.; Daellenbach, K. R.; Nussbaumer, T.; Geiser, M.; Prévôt, A. S. 497 H.; El-Haddad, I.; Cao, J.; Baltensperger, U.; Dommen, J. Predominance of Secondary Organic 498 Aerosol to Particle-Bound Reactive Oxygen Species Activity in Fine Ambient Aerosol. 499 Atmospheric Chem. Phys. 2019, 19 (23), 14703-14720. https://doi.org/10.5194/acp-19-147035002019. 
502

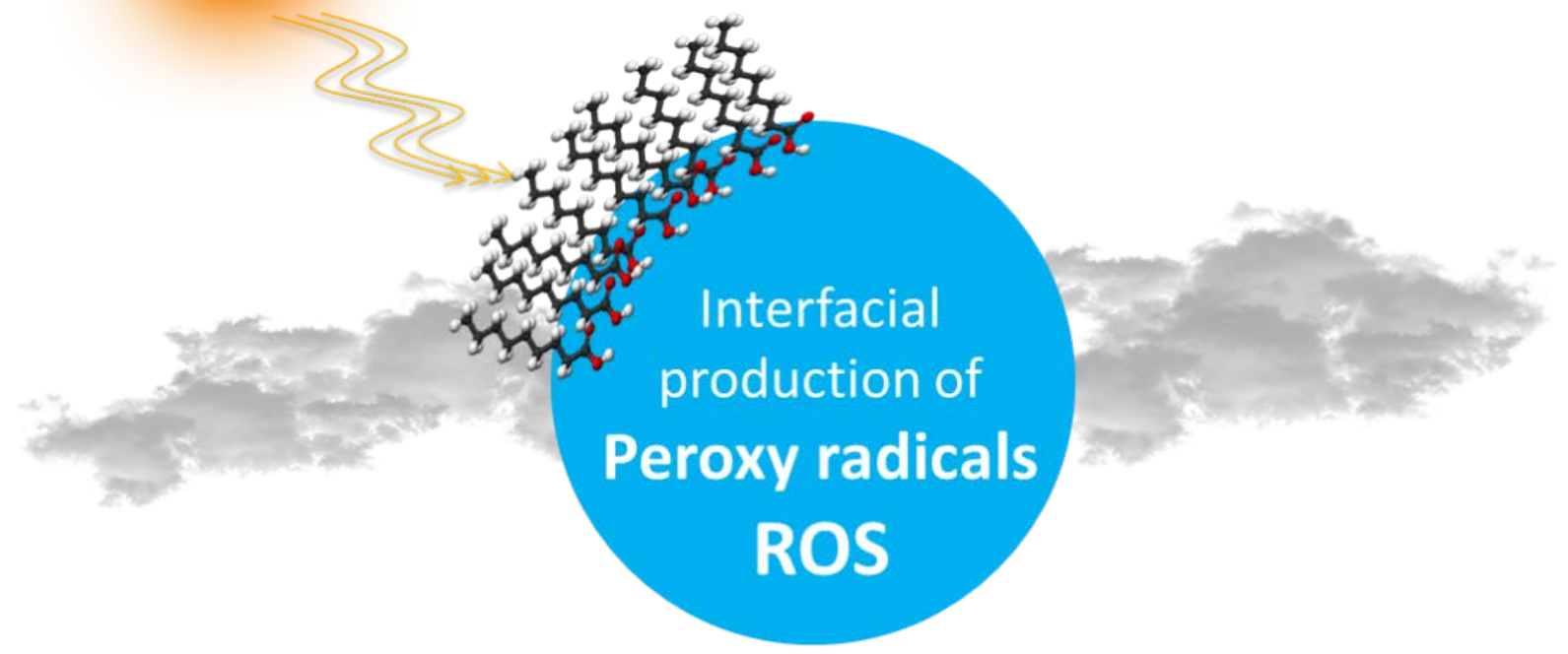

503

504 